\title{
Glucose Storage and Oxidation in Different Degrees of Human Obesity Measured by Continuous Indirect Calorimetry
}

\author{
J.-P. Felber, H. U. Meyer, B. Curchod ${ }^{2}$, H. U. Iselin, J. Rousselle, E. Maeder, P. Pahud ${ }^{1}$, and E. Jéquier ${ }^{1}$ \\ Divisions de Biochimie Clinique et de 'Physiologie Clinique, Centre Hospitalier Universitaire Vaudois, \\ and ${ }^{2}$ Policlinique Médicale Universitaire, Lausanne, Switzeriand
}

Summary. Glucose disposal of a $100 \mathrm{~g}$ glucose load has been determined in 26 obese compared with 10 non-obese subjects by means of a new application of continuous indirect calorimetry. The obese subjects were divided into 4 groups, according to their degree of glucose intolerance and their insulin response to the glucose load. Through this division it appeared that subjects with no glucose intolerance were moderately obese while the groups with glucose intolerance showed a higher degree of obesity, glucose intolerance increasing with age. The 10 obese subjects with no glucose intolerance (group A) presented values for glucose disposal similar to those of the control subjects. The 4 obese subjects with impaired glucose tolerance. (group B) showed no significant changes in glucose storage and in basal oxidation, but a significant decrease in oxidation in response to the load $(11 \pm 2 \mathrm{~g}$ vs $19 \pm 1 \mathrm{~g}$ in the control group, $p<0.02)$. The 6 obese subjects with overt diabetes and elevated insulin response to the glucose load (group C) showed a significant decrease in glucose storage ( $34 \pm 6 \mathrm{~g}$ vs $63 \pm 1 \mathrm{~g}, \mathrm{p}<0.001$ ) but not in oxidation. The 6 obese subjects with overt diabetes and decreased insulin response (group D) showed a significant decrease in glucose storage $(25 \pm 4 \mathrm{~g}$ vs 63 $\pm 1 \mathrm{~g}, \mathrm{p}<0.001)$ and oxidation $(12 \pm 1 \mathrm{~g}$, vs $19 \pm$ $1 \mathrm{~g}, \mathrm{p}<0.005)$. These observations show that in obese diabetics, glucose intolerance results primarily from decreased glucose storage and to a lesser extent from a decrease in glucose oxidation.

Key words: Diabetes, obesity, glucose storage, glucose oxidation, indirect calorimetry, oral glucose tolerance test, glucose intolerance.

The relationship between diabetes and obesity has been known for many years $[1,2,3]$. Abnormalities of carbohydrate metabolism are frequently encoun- tered in obese subjects, with various degrees of glucose intolerance from mild impairment to overt diabetes with either maintained insulin secretion, or marked insulin deficiency.

Two major metabolic mechanisms are responsible for glucose utilization and therefore determine glucose tolerance: glucose storage and glucose oxidation. After glucose ingestion, a major part of glucose is retained in the liver where it is used for glycogen synthesis and triglyceride formation [4]. A small fraction serves to replace glucose produced by the liver in the basal state, while another rather small fraction is oxidized at the periphery in response to the glucose load.

A new application of continuous indirect calorimetry has been developed to make a quantitative estimation of glucose storage and oxidation after an oral glucose load $[5,6]$. This method offers the advantage of being non invasive and is easily reproducible.

The purpose of the present study was to measure the modifications of glucose storage and oxidation in obese subjects with different degrees of glucose intolerance and to study the relationship between the changes in glucose tolerance and those of glucose disposal.

\section{Materials and Methods}

\section{a) Subjects}

Twenty-six obese subjects were studied (Table 1). Their weights were in all cases above $120 \%$ of their ideal body weight (IBW), according to the Metropolitan Life Insurance Tables (1959). The protocol was submitted to and accepted by an ethical committee. All subjects gave their informed consent before the studies.

The control group consisted of 10 normal volunteers. It is part of another study [6]. The mean age was $24 \pm 1$ years and the body weight was $95 \pm 2 \%$ of IBW.

As some of the obese subjects were older, another group of 5 normal nonobese volunteers was added. The mean age was $55 \pm 3$ years and the subjects were within $105 \pm 3 \%$ of their IBW. 
Table 1. Classification and characteristics of the subjects

\begin{tabular}{|c|c|c|c|}
\hline Subjects & Sex & Age & $\begin{array}{l}\text { \% ideal } \\
\text { body weight }\end{array}$ \\
\hline \multicolumn{4}{|l|}{ Group $A$} \\
\hline 1 & $F$ & 17 & 130 \\
\hline 2 & $\mathrm{~F}$ & 21 & 123 \\
\hline 3 & $F$ & 16 & 132 \\
\hline 4 & $F$ & 16 & 129 \\
\hline 5 & $F$ & 23 & 121 \\
\hline 6 & $\mathrm{M}$ & 43 & 124 \\
\hline 7 & $\mathbf{M}$ & 24 & 129 \\
\hline 8 & $\mathrm{M}$ & 32 & 136 \\
\hline 9 & $\mathrm{M}$ & 30 & 126 \\
\hline 10 & $M$ & $\frac{22}{24}+3$ & $\frac{131}{128+2}$ \\
\hline \multicolumn{4}{|l|}{ Group B } \\
\hline 1 & $\mathrm{~F}$ & 19 & 158 \\
\hline 2 & $\mathrm{M}$ & 26 & 137 \\
\hline 3 & $\mathrm{M}$ & 58 & 200 \\
\hline 4 & $\mathrm{~F}$ & 19 & 173 \\
\hline & & $31 \pm 9$ & $167 \pm 13$ \\
\hline \multicolumn{4}{|l|}{ Group C } \\
\hline 1 & $F$ & 34 & 215 \\
\hline 2 & $F$ & 18 & 200 \\
\hline 3 & $\mathrm{M}$ & 47 & 127 \\
\hline 4 & $\mathrm{~F}$ & 41 & 209 \\
\hline 5 & $\mathrm{~F}$ & 55 & 155 \\
\hline \multirow[t]{2}{*}{6} & $\mathrm{~F}$ & 62 & 125 \\
\hline & & $43 \pm 6$ & $172 \pm 17$ \\
\hline \multicolumn{4}{|l|}{ Group $D$} \\
\hline 1 & $F$. & 55 & 132 \\
\hline 2 & $F$ & 43 & 236 \\
\hline 3 & $\mathrm{~F}$ & 66 & 128 \\
\hline 4 & $\mathrm{M}$ & 48 & 122 \\
\hline 5 & $M$ & 35 & 261 \\
\hline \multirow[t]{2}{*}{6} & $M$ & 68 & $\underline{132}$ \\
\hline & & $\overrightarrow{53} \pm 5$ & $\overline{169} \pm 26$ \\
\hline Control group & & & \\
\hline $\begin{array}{l}\text { (non obese) } \\
\mathrm{n}=10\end{array}$ & $\begin{array}{l}6 \times F \\
4 \times M\end{array}$ & $24 \pm 1$ & $95 \pm 2$ \\
\hline Control group & & & \\
\hline (non obese older & $3 \times \mathrm{F}$ & $55 \pm 3$ & $105 \pm 3$ \\
\hline subjects) $n=5$ & $2 \times M$ & & \\
\hline
\end{tabular}

The obese subjects were divided into 4 groups according to their degree of glucose intolerance and to the insulin response to the glucose load. Age and percent ideal body weight of each group are seen in Table 1.

Group $A$ consisted of 10 obese diabetics whose glucose tolerance curve was within normal limits, after a $100 \mathrm{~g}$ oral glucose load Plasma glucose was $86 \pm 2 \mathrm{mg} / \mathrm{dl}$ at time 0 and $95 \pm 5 \mathrm{mg} / \mathrm{dl}$ after $2 \mathrm{~h}$.

Group $B$ consisted of 4 obese diabetics with impaired glucose tolerance. Plasma glucose was $84 \pm 4 \mathrm{mg} / \mathrm{dl}$ at time 0 , and $159 \pm$ $10 \mathrm{mg} / \mathrm{dl}$ after $2 \mathrm{~h}$. They presented an hyperinsulinaemic response to the glucose load.

Group $C$ consisted of 6 obese diabetics with overt diabetes and increased insulin response (in comparison to the normal group). Plasma glucose was $139 \pm 17 \mathrm{mg} / \mathrm{dl}$ at time 0 and $266 \pm 45 \mathrm{mg} / \mathrm{dl}$ after $2 \mathrm{~h}$.

Group $D$ consisted of 6 obese diabetics with overt diabetes but low insulin response to the oral glucose load. Plasma glucose was 271 $\pm 28 \mathrm{mg} / \mathrm{dl}$ at time 0 and $456 \pm 25 \mathrm{mg} / \mathrm{dl}$ after $2 \mathrm{~h}$.

\section{b) Experimental Protocol}

All subjects received an equilibrated diet with a minimal intake of $250 \mathrm{~g}$ carbohydrate a day and were not on any medication for at least $48 \mathrm{~h}$ prior to the study. In all cases, the test was performed after an overnight fast of at least $10 \mathrm{~h}$.

The subjects were administered a $100 \mathrm{~g}$ oral glucose load in $400 \mathrm{ml}$ lemon flavoured water. The oral glucose tolerance test was performed during continuous indirect calorimetry. Blood was withdrawn from an antecubital vein every $30 \mathrm{~min}$, starting $30 \mathrm{~min}$ before the glucose load, for measurements of glucose, immunoreactive insulin (IRI) and non esterified fatty acids (NEFA).

Two urine samples were collected: one overnight, the other for the duration of the test. These were used to calculate urinary glucose and nitrogen.

\section{c) Gas-exchange Measurements}

Continuous indirect calorimetry was performed as previously described $[6,7,8]$. It allows determinations of both carbohydrate and lipid oxidation rates as well as calculation of the total quantity of glucose and lipid oxidized during the period of the test, the quantity of glucose oxidized at basal rate and in response to the load (suprabasal oxidation). The quantity of glucose stored during the 3 hours of the test was calculated by subtracting from the $100 \mathrm{~g}$ ingested glucose, the total quantity of glucose oxidized, urinary glucose loss and excess glucose remaining in the glucose space. The glucose space was considered to represent $25 \%$ of the body weight of the subjects [9]. Glucose storage, in this study, corresponds to glucose taken up by tissues without being oxidized, i. e. essentially to glycogen synthesis and deposition. The values of glucose disposal obtained in normal subjects by this method correspond well $[5 ; 6]$ to those obtained by Felig et al. [10] in their study of splanchnic glucose exchange, using a method based on simultaneous measurement of glucose in hepatic venous and brachial arterial blood.

\section{d) Analytical Procedures}

Plasma and urinary glucose were measured by the hexokinase method; plasma immunoreactive insulin (IRI) according to the method described by Herbert et al. [11]; plasma non-esterified fatty acids (NEFA) according to Dole and Meinertz [12]; and urinary nitrogen by the method of Kjeldahl [13].

\section{e) Statistical Methods}

All data are presented as mean \pm SEM. The statistical comparisons between obese and control groups were calculated by means of the unpaired t-test analyses.

\section{Results}

The values for glucose disposal together with the plasma glucose IRI curves in the two control groups of 10 young and 5 older non-obese normal subjects and the four groups of obese subjects are presented in Figure 1. NEFA levels and values of total lipid oxidation are seen in Table 2.

In the control group of younger subjects $63 \pm 1 \mathrm{~g}$ glucose were stored during the 3 hours following the $100 \mathrm{~g}$ glucose load, $20 \pm 2 \mathrm{~g}$ were oxidized in the 

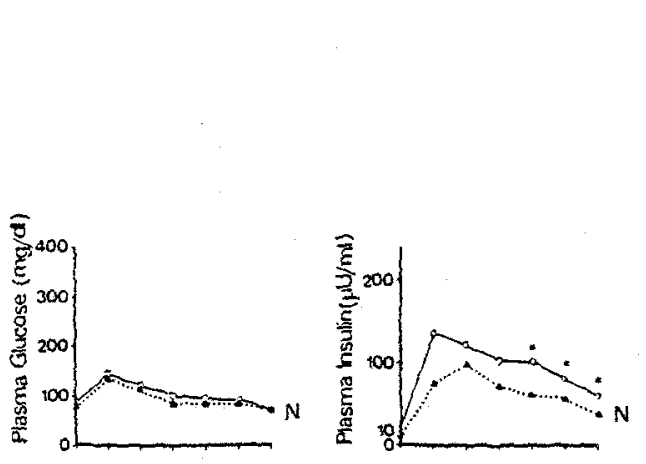

\begin{tabular}{|c|c|c|c|c|c|}
\hline & $\begin{array}{l}\text { Basal } \\
\text { oxidation }\end{array}$ & $\begin{array}{l}\text { Suprabasal } \\
\text { oxidation }\end{array}$ & $\begin{array}{l}\text { Changes in } \\
\text { glucose space }\end{array}$ & $\begin{array}{l}\text { Urinary } \\
\text { loss }\end{array}$ & $\begin{array}{l}\text { Glucose } \\
\text { storage }\end{array}$ \\
\hline & & $19 \pm 1$ & $-2 \pm 1$ & 0 & 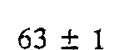 \\
\hline
\end{tabular}
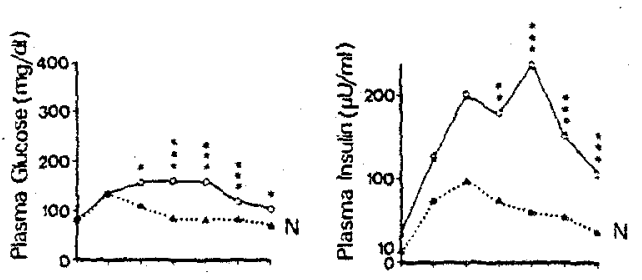

Normal subjects (older group)

$\mathrm{n}=5 \quad 17 \pm 1 \quad 21 \pm 1$

0

0

$62 \pm 2$

$\begin{array}{llllll}\text { Ob A } & 17 \pm 1 & 22 \pm 2 & -3 \pm 1 & 0 & 64 \pm 2 \\ \mathbf{n}=10 & \text { NS } & \text { NS } & \text { NS } & & \text { NS }\end{array}$
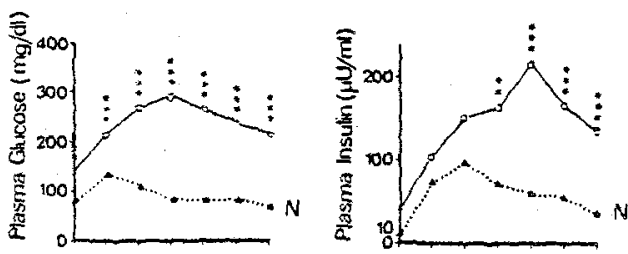

\begin{tabular}{|c|c|c|c|c|}
\hline $\begin{array}{l}O b B \\
n=4\end{array}$ & $\begin{array}{l}23 \pm 1 \\
\text { NS }\end{array}$ & $\begin{array}{l}11 \pm 2 \\
p<0.02\end{array}$ & $\begin{array}{l}+6 \pm 3 \\
p<0.01\end{array}$ & 0 \\
\hline
\end{tabular}
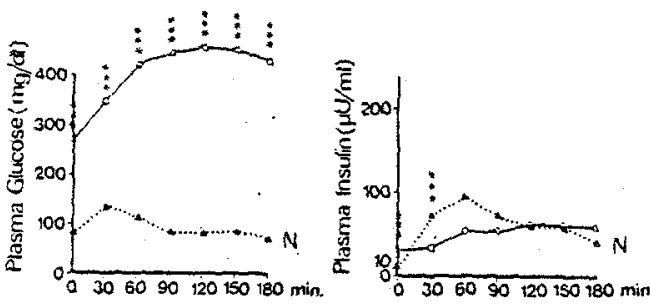

$\begin{array}{llll}\mathrm{Ob} \mathrm{C} & 20 \pm 2 & 21 \pm 1 & +21 \pm 7 \\ \mathrm{n}=6 & \mathrm{NS} & \text { NS } & \mathrm{p}<0.005\end{array}$

$4 \pm 3 \quad 34 \pm 6$ $\mathrm{p}<0.001$

Fig. 1. Plasma glucose and insulin levels (left) and values of disposal ( $\mathrm{g}$ glucose \pm SEM) of the $100 \mathrm{~g}$ oral glucose load after $180 \mathrm{~min}$ (right) in the four groups of obese subjects $(\mathrm{Ob} A, \mathrm{~B}, \mathrm{C}, \mathrm{D})$ and in the two groups of non obese normal controls. Statistical signiticance of the differences is given in comparison with the non obese control group $(n=10){ }^{*}=p<0.05 ; * *=p<0.02 ; * * *=p<0.001$

basal state and $19 \pm 1 \mathrm{~g}$ were oxidized in response to the load. A decrease of $2 \pm 1$ g glucose was observed in the giucose space at the end of the 3 -hour period of the test. The values were not significantly different in the older group, with $17 \pm 1 \mathrm{~g}$ for basal glucose oxidation, $21 \pm 1 \mathrm{~g}$ for suprabasal oxidation and 62 $\pm 2 \mathrm{~g}$ for glucose storage. No urinary loss and no significant changes were observed in the glucose space.

In group A composed of 10 obese subjects with normal glucose tolerance, the glucose tolerance curve did not significantly differ from that of the non-obese control group, with a mean fasting plasma glucose level of $86 \pm 2 \mathrm{mg} / \mathrm{dl}$ and a peak of $143 \pm 6 \mathrm{mg} / \mathrm{dl}$ at $30 \mathrm{~min}$. Mean plasma IRI levels were however, significantly higher $(p<0.05)$ at 120,150 and $180 \mathrm{~min}$. Plasma NEFA levels were $498 \pm 47 \mu \mathrm{mol} / 1$ at time 0 , in comparison with $460 \pm 53 \mu \mathrm{mol} / \mathrm{l}$ in the control group (Table 2).
Glucose disposal showed no significant difference from the control group with $64 \pm 2 \mathrm{~g}$ glucose stored over the 3 hours of the test, $17 \pm 1 \mathrm{~g}$ glucose oxidized in the basal state and $22 \pm 2$ g glucose oxidized above basal oxidation. A decrease of $3 \pm 1 \mathrm{~g}$ glucose was observed in the glucose space. There was no significant urinary loss. Total lipid oxidized during the test was $7 \pm 1$, compared to $5 \pm 1 \mathrm{~g}$ in the control group (Table 2).

In group B composed of 4 obese subjects with impaired glucose tolerance, the mean fasting plasma glucose level was within normal limits at $84 \pm 4 \mathrm{mg} /$ dl. Glucose levels continued to increase after $30 \mathrm{~min}$, to reach a plateau of $159 \pm 14$ and $159 \pm 10 \mathrm{mg} / \mathrm{dl}$ at 60 and $120 \mathrm{~min}$ respectively. Mean plasma insulin levels $(34 \pm 2 \mu \mathrm{U} / \mathrm{ml})$, already significantly higher than in the control group in the fasting state, increased markedly to reach a peak of $239 \pm 42 \mu \mathrm{U} /$ $\mathrm{ml}$ at $120 \mathrm{~min}$. Values were significantly higher than 
Table 2. Fasting plasma NEFA levels and total lipid oxidation during the oral glucose tolerance test

\begin{tabular}{|c|c|c|c|}
\hline & $\mathbf{n}$ & $\begin{array}{l}\text { NEFA } \\
\mu \mathrm{mol} / /\end{array}$ & $\begin{array}{l}\text { Total lipid oxidation } \\
\text { g/180 } \mathrm{min}\end{array}$ \\
\hline $\begin{array}{l}\text { Control group } \\
\text { (non obese) }\end{array}$ & 10 & $460 \pm 53$ & $5 \pm 1$ \\
\hline Group A & 10 & $\begin{array}{l}498 \pm 47 \\
\text { NS }\end{array}$ & $\begin{array}{l}7 \pm 1 \\
\text { NS }\end{array}$ \\
\hline Group B & 4 & $\begin{array}{l}637 \pm 93 \\
p<0.05\end{array}$ & $\begin{array}{l}12 \pm 3 \\
p<0.001\end{array}$ \\
\hline Group C & 6 & $\begin{array}{l}458 \pm 79 \\
\text { NS }\end{array}$ & $\begin{array}{c}9 \pm 1 \\
p<0.001\end{array}$ \\
\hline Group D & 6 & $\begin{array}{l}540 \pm 135 \\
\text { NS }\end{array}$ & $\begin{array}{l}12 \pm 3 \\
p<0.05\end{array}$ \\
\hline
\end{tabular}

Statistical differences are expressed in comparison with the non obese control group

those of the control group at $0,90,120,150$ and $180 \mathrm{~min}$. The mean fasting plasma NEFA levels were elevated at $637 \pm 93 \mu \mathrm{mol} / \mathrm{l}$.

Glucose disposal showed no significant change in glucose storage $(60 \pm 2 \mathrm{~g})$ in comparison with the control group, during the 3 hours of the test. Glucose oxidation in response to the load, however, was significantly decreased $(11 \pm 2 \mathrm{~g})$ while basal glucose oxidation $(23 \pm 1 \mathrm{~g})$ was within normal limits. A minimal amount of glucose was in excess in the glucose space at the end of the 3 hours. There was no significant urinary loss. Total lipid oxidation during the test was significantly increased $(12 \pm 3 \mathrm{~g}$ ) (Table 2).

In group C, 6 obese subjects with overt diabetes and increased insulin response, all the values of the glucose curve were significantly higher than those of the control group. Fasting plasma insulin levels ( $42 \pm$ $6 \mu \mathrm{U} / \mathrm{ml}$ ) were significantly higher than in the control group. A peak of $215 \pm 43 \mu \mathrm{U} / \mathrm{ml}$ was reached at $120 \mathrm{~min}$. IRI values were significantly elevated in comparison with the control group, at $0,90,120,150$ and $180 \mathrm{~min}$. Fasting plasma NEFA $(458 \pm 79 \mu \mathrm{mol} / 1)$ were not significantly different from those of the control group.

Calculation of glucose disposal showed a significant decrease in the quantity of glucose stored (34 \pm $6 \mathrm{~g})$. Glucose oxidation in the basal state $(20 \pm 2 \mathrm{~g})$ and in response to the load $(21 \pm 1 \mathrm{~g})$ was not different from the oxidation in the control group. At the end of the 3-hour period $21 \pm 7 \mathrm{~g}$ glucose were in excess in the glucose space and $4 \pm 3 \mathrm{~g}$ were lost in the urine. Total lipid oxidation during the 3 hours of the test was increased to $9 \pm 1 \mathrm{~g}$ (Table 2).

In group $D$, the 6 obese subjects with overt diabetes and decreased insulin response to the glucose load, plasma glucose levels were significantly elevated in every sample of the glucose curve. Fasting plasma insulin $(34 \pm 4 \mu \mathrm{U} / \mathrm{ml})$ was higher than in the control group. However, the response to the load was significantly decreased at $30 \mathrm{~min}(35 \pm 5 \mu \mathrm{U} / \mathrm{ml})$ in comparison with the control response, and plasma IRI levels were maintained as a plateau between 50 and $60 \mu \mathrm{U} / \mathrm{ml}$ from 60 to $180 \mathrm{~min}$. Fasting plasma NEFA levels were not significantly increased (540 \pm $135 \mu \mathrm{mol} / 1)$.

Calculation of glucose disposal showed a significant decrease in the glucose stored $(25 \pm 4 \mathrm{~g}$ ), oxidized at basal rate $(12 \pm 2 \mathrm{~g})$ and in response to the load $(12 \pm 1 \mathrm{~g})$. Excess glucose in the glucose space was $29 \pm 6 \mathrm{~g}$ and urinary loss $22 \pm 4 \mathrm{~g}$. The total amount of lipid oxidation during the test period was increased to $12 \pm 3 \mathrm{~g}$ (Table 2).

\section{Discussion}

The values for glucose disposal in the control group were almost identical to those previously reported [5], confirming the reproducibility of the method in estimating glucose oxidation and storage.

Measurement of glucose disposal in obese subjects with different degrees of glucose intolerance shows that deficiency of either glucose oxidation or glucose storage, or of both simultaneously, is involved in the impairment of glucose utilization. The division of the obese subjects into 4 groups, from normal glucose tolerance to impaired glucose tolerance, overt diabetes with high and low insulin response to the glucose load, corresponds to differences in the severity of the disease. Although the number of obese subjects included in the present study is rather small, it appears that subjects withouth glucose intolerance (group A) were mildly obese and younger than those with a higher degree of obesity. Furthermore, glucose intolerance was increased with increasing age (groups $B, C$ and $D$ ).

In group $A$, the patients with normal glucose tolerance, plasma insulin levels were already significantly elevated at $0,120,150$ and $180 \mathrm{~min}$. This group did not present any alteration of glucose storage and oxidation, in comparison with the normal non-obese group.

Patients from group B, obese subjects with impaired glucose tolerance, presented increased plasma insulin and NEFA levels. Study of glucose disposal showed no change in glucose storage, but a significant decrease in glucose oxidation in response to the load. This observation suggests that the elevated plasma glucose levels in the second part of the glucose curve probably result from this defect. Deficiency in glucose oxidation in response to the load is indeed expected to affect mostly the late phase of the glucose tolerance curve as oxidation is normally low at the beginning of the test and gradually increases to reach its maximum after 90 to $150 \mathrm{~min}[8,14]$. 
In group $C$ made up of obese hyperinsulinaemic subjects with overt diabetes, study of glucose disposal showed a significant decrease in glucose storage, while glucose oxidation was within the normal range. The marked insulin resistance demonstrated by glucose intolerance together with high plasma insulin levels was, therefore, not associated with an alteration in glucose oxidation, but with a deficiency in glucose storage. It is not surprising that glucose oxidation was not decreased, since elevation of plasma glucose levels together with the absence of any significant increase in fasting plasma NEFA levels should favour glucose oxidation. Chevaux et al. [15] have indeed demonstrated that elevation of glucose levels at constant insulin levels causes the carbohydrate oxidation to increase.

In the last group (group D) of obese diabetics with low insulin response to the glucose load, glucose intolerance was increased more even than in the preceding groups. The patients showed a decrease in both glucose storage and oxidation. Glucose storage deficiency was definitely a consequence of the decrease in insulin secretion, although insulin resistance is not excluded as an additional factor. The moderate decrease in glucose oxidation might be related both to impaired insulin secretion (which could cause a decrease glucose uptake by the peripheral tissues) and to an increase in lipid oxidation $(12 \mathrm{~g}$ vs $5 \mathrm{~g}$ in the control group during the 3 hours of the test).

It appears from these different observations that alteration of either glucose oxidation or glucose storage may affect glucose tolerance in obesity. In some cases of obesity with glucose intolerance (group B), the latter may result only from decreased glucose oxidation as a result of preferential lipid oxidation which is a consequence of the increased plasma FFA levels. As shown by Flatt [16], the increase in NEFA levels in obesity, in spite of hyperinsulinism is a direct consequence of the extensive increase in the adipose tissue mass. It does not have to be the result of a reduced sensitivity of the fat cells to insulin. In group $B$, the decrease in glucose oxidation in response to the load corresponds to an increase in total lipid oxidation, from $5 \mathrm{~g}$ in the control group to $12 \mathrm{~g}$ during the 3 hours of the test in the obese group. This observation is in line with the glucose fatty-acid cycle concept proposed by Randle et al. [17] and further investigated in humans by others $[7,18,19,20]$.

It appears evident that deficiency in glucose oxidation in response to the load should only affect glucose tolerance to a limited extent since, as suggested by Felig et al. [10], only a small portion of the ingested glucose is available for disposal by the peripheral tissues as increased (above basal) glucose utilization.
Cases of overt diabetes both with high or decreased insulin response to the glucose load, show a marked reduction in glucose storage. Deficiency in glucose storage is expected to affect glucose tolerance to a greater extent than deficiency in glucose oxidation. The importance of the liver in glucose disposal was first demonstrated by Scow and Cornfield [21] and Perley and Kipnis [22]. Felig and Wahren [23] confirmed the major role of the liver in glucose uptake by means of direct measurements of splanchnic glucose output in normal subjects. They reported that 55 to $60 \mathrm{~g} \mathrm{[4]} \mathrm{of} \mathrm{a} 100 \mathrm{~g}$ oral glucose load were stored in the liver after 3 hours.

A defect in glucose storage after carbohydrate ingestion is expected to cause glucose intolerance. In physiological conditions, a large fraction of absorbed glucose is stored within 3 hours as liver glycogen which serves as a "reservoir" for glucose. Deficiency in the capacity of this reservoir results in a long lasting increase in glucose in the plasma and the extracellular space. During the 3 hours of observation used in the present study, which correspond to the conventional oral glucose tolerance test, an impaired storage of ingested glucose appears therefore to be a major cause of severe glucose intolerance.

Calculation of glucose disposal in obese diabetics of group D confirms the effect of insulin deficiency on decreased glucose storage. However, insulin deficiency does not appear to be the only cause for decreased glucose storage. Obese diabetics of group $C$ did not lack insulin, as shown by their high insulin response to the glucose load. Their defect in glucose storage is probably due to a decrease in the capacity of the liver to store glucose, knowing the important role played by this organ in glucose uptake. This decreased capacity of the liver to store glucose in the presence of increased insulin secretion suggests that the liver is probably the main focus of insulin resistance in these patients as previously proposed by Felig and Wahren [23].

Decrease in insulin binding to receptors may certainly play a role in insulin resistance in animal and human obesity $[24,25,26,27,28]$. Evidence is, however, given both in animals [29] and in humans [30, 31] that decrease in the number of insulin receptors is secondary to hyperinsulinism and is not the primary cause of insulin resistance in obesity. In most patients it appears to be caused by a metabolic abnormality beyond the receptor levels $[32,33]$.

The application of continuous indirect calorimetry to the study of glucose disposal shows that glucose intolerance results, in the obese diabetic, both from decreased glucose oxidation, which plays a minor role, and decreased glucose storage. Defect in glucose storage can result from insulin deficiency, but probably also from an insulin-independent decreased capacity of the liver to store glucose. 
Acknowledgements. This work was partly supported by the Raymond Berger Fund for Diabetes Research. The authors thank Dr. E. Jacot and Dr. Ch. Broquet for their help and Miss B. Morel and Mr. M. Lavanchy for their technical assistance.

\section{References}

1. Joslin EP (1959) Obesity and diabetes. In: Joslin EP, Root HF, White P, Marble A (eds) The treatment of diabetes mellitus. Lea \& Febiger, Philadelphia, p 64-75

2. Smith M, Levine R (1964) Obesity and diabetes. Med Clin North Am 48: 1387-1397

3. Pfeiffer EF, Laube $H$ (1974) Obesity and diabetes mellitus. Adv Metab Disord 7: 243-255

4. Sherwin R, Felig P (1978) Pathophysiology and diabetes mellitus. Med Clin North Am 62: 695-711

5. Felber JP, Iselin HU, Acheson K, Pahud P, Jéquier E (1979) Carbohydrate storage and oxidation in obesity and diabetes. In: Vague J, Vague Ph (eds) Diabetes and obesity. Proc. Fifth Int. Meeting of Endocrinol., Marseille 1978. Excerpta Medica, Amsterdam Oxford, p 243-252

6. Meyer HU, Curchod B, Maeder E, Pahud P, Jéquier E, Felber JP (1980) Modification of glucose storage and oxidation in non obese diabetics measured by continuous indirect calorimetry. Diabetes 29: 752-756

7. Gomez F, Jéquier E, Chabot V, Büber V, Felber JP (1972) Carbohydrate and lipid oxidation in normal human subjects: its influence on glucose tolerance and insulin response to glucose. Metabolism 21: 381-391

8. Felber JP, Magnenat G, Casthélaz M, Geser CA, Muller-Hess $\mathrm{R}$, de Kalbermatten $\mathrm{N}$, Ebiner JR, Curchod $\mathrm{B}$, Pittet $\mathrm{Ph}$, Jéquier $\mathrm{E}$ (1977) Carbohydrate and lipid oxidation in normal and diabetic subjects. Diabetes 26: 693-699

9. Steele R, Wall JS, de Bodo RC, Altszuler N (1956) Measurement of size and turnover rate of body glucose pool by the isotope dilution method. Am J Physiol 187: 15-24

10. Felig P, Wahren J, Hendler R (1975) Influence of oral glucose ingestion on splanchnic glucose and gluconeogenic substrate metabolism in man. Diabetes 24: 468-475

11. Herbert V, Lau KS, Gottlieb CW, Bleicher SJ (1965) Coated charcoal immunoassay of insulin. I Clin Endocrinol Metab 25: 1375-1384

12. Dole VP, Meinertz $H$ (1960) Microdetermination of a longchain fatty acids in plasma and tissues. $\mathrm{J}$ Biol Chem 235: 2595-2599

13. Hawk PB (1947) Practical physiological chemistry, 12th ed: Kjeldahl method. Blakiston, Toronto, p 814-822

14. Ebiner JR, Acheson KJ, Doerner A, Maeder E, Amaud MJ, Jéquier E, Felber JP (1979) Comparison of carbohydrate utilization in man using indirect calorimetry and mass spectrometry after an oral load of $100 \mathrm{~g}$ naturally labelled $\left({ }^{13} \mathrm{C}\right)$ glucose. Br I Nutr 41: $419-429$

15. Chevaux F, Maeder E, Ravussin E, Jéquier E (1976) Study by indirect calorimetry of the oxidation rate of carbohydrate in man at two different plasma insulin levels (abstract). Diabetologia 12: 383

16. Flatt JP (1972) Role of the increased adipose tissue mass in the apparent insulin insensitivity of obesity. Am J Clin Nutr 25: 1189-1192
17. Randle PJ, Hales CN, Garland PB, Newsholme EA (1963) The glucose fatty-acid cycle. Its role in insulin sensitivity and the metabolic disturbances of diabetes mellitus. Lancet I: 785-789

18. Felber JP, Vannotti A (1964) Effects of fat infusion on glucose tolerance and insulin plasma levels. Med Exp 10: 153-156

19. Schalch DS, Kipnis DM (1965) Abnormalities in carbohydrate tolerance associated with elevated plasma nonesterified fatty acids. J Clin Invest 44: 2010-2020

20. Balasse EO, Neef MA (1974) Operation of the ,glucose-fatty acid cycle" during experimental elevations of plasma free fatty acid levels in man. Eur J Clin Invest 4: 247-252

21. Scow RO, Cornfield J (1954) Quantitative relations between oral and intravenous glucose tolerance curves. Am J Physiol 179: $435-438$

22. Perley MJ, Kipnis DM (1967) Plasma insulin responses to oral and intravenous glucose: studies in normal and diabetic subjects. J Clin Invest 46: 1951-1962

23. Felig $P$, Wahren $J(1975)$ The liver as site of insulin and glucagon action in normal, diabetic and obese humans. Isr J Med Sci 11: 528-539

24. Soll AH, Kahn CR, Neville DM Jr, Roth J (1975) Insulin receptor deficiency in genetic and acquired obesity. $J$ Clin Invest 56: 769-780

25. Archer JA, Gorden P, Roth J (1975) Defect in insulin binding to receptors in obese man. Amelioration with caloric restriction. J Clin Invest $55: 166-174$

26. Bar RS, Gorden P, Roth J, Kahn CR, De Meyts P (1976) Fluctuations in the affinity and concentration of insulin receptors on circulating monocytes of obese patients: effects of starvation, refeeding and dieting. J Clin Invest 58: 1123-1135

27. Olefsky JM (1976) Decreased insulin binding to adipocytes and circulating monocyte from obese subjects. J Clin Invest 57: $1165-1172$

28. Kolterman OG, Reaven GM, Olefsky IM (1979) Relationship between in vivo insulin resistance and decreased insulin receptors in obese man. J Clin Endocrinol Metab 48: $487-494$

29. Assimacopoulos-Jeannet F, Jeanrenaud B (1976) The hormonal and metabolic basis of experimental obesity. Clin Endocrinol Metab 5: 337-365

30. Bar RS, Roth I (1977) Insulin receptor status in disease states of man. Arch Intern Med 137: 474-481

31. Wigand JP, Blackard WG (1979) Downregulation of insulin receptors in obese man. Diabetes 28: 287-291

32. Misbin RI, O'Leary JP, Pulkkinen A (1979) Insulin receptor binding in obesity: a reassessment. Science 205: 1003-1004

33. DeFronzo RA, Soman V, Sherwin RS, Hendler R, Felig P (1978) Insulin binding to monocytes and insulin action in human obesity, starvation and refeeding. $J$ Clin Invest 62 : 204-213

Received: November 29, 1979 ,

and in revised form: September 1, 1980

Prof. J.-P. Felber

Division de Biochimie Clinique

Département de Médecine

C.H.U.V.

$\mathrm{CH}-1011$ Lausanne

Switzerland 